\title{
Commentary
}

\section{Potential Use of Pharmacogenetics to Reduce Drug-Induced Syndrome of Inappropriate Antidiuretic Hormone (SIADH)}

\author{
Russell A. Wilke
}

Citation: Wilke, R.A. Potential Use of Pharmacogenetics to Reduce Drug-Induced Syndrome of Inappropriate Antidiuretic Hormone (SIADH). J. Pers. Med. 2021, 11, 853. https://doi.org/10.3390/jpm11090853

Academic Editor: Latha Palaniappan

Received: 29 July 2021

Accepted: 26 August 2021

Published: 28 August 2021

Publisher's Note: MDPI stays neutral with regard to jurisdictional claims in published maps and institutional affiliations.

Copyright: (C) 2021 by the author. Licensee MDPI, Basel, Switzerland. This article is an open access article distributed under the terms and conditions of the Creative Commons Attribution (CC BY) license (https:/ / creativecommons.org/licenses/by/ $4.0 /)$.
Sanford School of Medicine, University of South Dakota, 1400 West 22nd Street, Sioux Falls, SD 57105, USA; russell.wilke@usd.edu

\begin{abstract}
Syndrome of inappropriate antidiuretic hormone (SIADH) is a common cause of hyponatremia, and many cases represent adverse reactions to drugs that alter ion channel conductance within the peptidergic nerve terminals of the posterior pituitary. The frequency of drug-induced SIADH increases with age; as many as $20 \%$ of patients residing in nursing homes have serum sodium levels below $135 \mathrm{mEq} / \mathrm{L}$. Mild hyponatremia is associated with cognitive changes, gait instability, and falls. Severe hyponatremia is associated with cerebral edema, seizures, permanent disability, and/or death. Although pharmacogenetic tests are now being deployed for some drugs capable of causing SIADH (e.g., antidepressants, antipsychotics, and opioid analgesics), the implementation of these tests has been based upon the prior known association of these drugs with other serious adverse drug reactions (e.g., electrocardiographic abnormalities). Work is needed in large observational cohorts to quantify the strength of association between pharmacogene variants and drug-induced SIADH so that decision support can be developed to identify patients at high risk.
\end{abstract}

Keywords: neurohypophysis; antidiuretic hormone; adverse drug reaction; drug safety

\section{Background}

Clinical derangements in salt and water homeostasis are common [1,2]. Hyponatremia (low serum sodium level) is the most common electrolyte abnormality seen in routine practice [3,4]. Mild hyponatremia (serum sodium $<135 \mathrm{mEq} / \mathrm{L}$ ) can lead to cognitive changes, gait instability, and falls. Severe hyponatremia (serum sodium $<125 \mathrm{mEq} / \mathrm{L}$ ) causes profound osmotic disturbances and fluid shifts in multiple organ systems. If left uncorrected, the accompanying fluid shifts lead to cerebral edema, seizures, disability, and/or death [5]. The societal cost of this problem is enormous [6,7].

Age is a strong predictor of hyponatremia. Nearly one in five patients residing in nursing homes have serum sodium levels below $135 \mathrm{mEq} / \mathrm{L}$, and this patient population is at risk of serious injury if they fall [8]. In a series of 696 emergency room patients with advanced age (mean age $86.1 \pm 5.6$ years), the prevalence of mild hyponatremia was $26 \%$ in patients with falls (95\% CI: $19.8-32.4)$, and $13 \%$ in patients without falls $(95 \%$ CI: 10.1-16.3) [9]. In the inpatient setting, the prevalence of mild hyponatremia is $6 \%$ on general medical wards (95\% CI 5.9-6.1), and $22 \%$ on geriatric wards (95\% CI 20.2-24.3) [8]. Severe hyponatremia occurs at a rate of $1 \%$ on general wards $(95 \% \mathrm{CI} 0.7-0.8)$, and $4 \%$ on geriatric wards (95\% CI 3.0-6.1). When analyses are restricted to cases of very severe hyponatremia (serum sodium $<116 \mathrm{mEq} / \mathrm{L}$ ), the large majority of cases are drug-induced [10].

\section{Excessive Antidiuretic Hormone}

Hyponatremia can be caused by a variety of mechanisms. Clinical assessment begins with an assessment of volume status [3]. While hyponatremia can accompany volume contraction (e.g., renal salt wasting in dehydration) [11] or volume overload (e.g., uncompensated heart failure) [12], most cases occur in patients that are relatively euvolemic [1]. The presence of low serum sodium levels in a patient with normal volume status sug- 
gests the presence of a neuroendocrine abnormality such as hypothyroidism, adrenal insufficiency, or excessive amounts of circulating antidiuretic hormone (ADH).

Antidiuretic hormone, also called vasopressin, is a 9-amino acid peptide with a complex physiological role that includes the regulation of renal free water excretion and the maintenance of vascular tone [13]. Circulating ADH is primarily derived from nerve terminals of the posterior pituitary gland (the neurohypophysis). These peptidergic nerve terminals represent distal extensions of axons originating in the hypothalamus. They are structurally and functionally distinct from the glandular tissue of the anterior pituitary gland (the adenohypophysis). When serum sodium levels rise above $145 \mathrm{mEq} / \mathrm{L}$, hypothalamic osmoreceptors located in the supraoptic and paraventricular nuclei activate secretion of ADH directly from the posterior pituitary [14] (Figure 1A). The resulting increase in systemic levels of $\mathrm{ADH}$ then leads to enhanced water reabsorption by the kidneys. The binding of ADH to its receptors on the basolateral membrane of the renal collecting tubules leads to the insertion of aquaporin-2 water channels within the apical membrane, thereby facilitating the maintenance of osmotic homeostasis through the retention of free water. It is generally accepted that this finely tuned physiological process contributed to the survival of land-dwelling organisms during evolution.

While hypothalamic control of ADH release from the posterior pituitary is tightly regulated, this process is also highly sensitive to perturbation by a variety of endogenous and exogenous insults. Excessive ADH levels are commonly seen in patients with brain trauma [15], as well as in patients with space-occupying lesions (e.g., lymphoma) [16] or infections located in the base of the brain (e.g., meningitis) [17]. The link between infection and posterior pituitary dysregulation is not, however, restricted to infections of the central nervous system. Low serum sodium levels occur in as many as one in three patients with pneumonia, indicating that excessive ADH levels can accompany systemic infections as well [2,4]. During states of severe inflammation, cytokine-induced changes in posterior pituitary signal transduction tend to drive circulating levels of ADH upward with the undesirable effect of driving serum sodium levels downward. Within this context, hyponatremia is a strong predictor of mortality risk. In patients hospitalized with COVID19 , for example, each $1 \mathrm{mEq} / \mathrm{L}$ drop in serum sodium level is associated with a $14 \%$ increase in the risk of death [4].

Thus, elevated levels of ADH can be adaptive (e.g., to maintain blood volume during states of poor cardiac output such as congestive heart failure) or maladaptive (e.g., during states of severe inflammation). Maladaptive elevation in circulating ADH level—causing an inappropriately high urine osmolality and decreased serum sodium level in a patient with adequate blood volume-is frequently referred to as the "syndrome of inappropriate antidiuretic hormone (SIADH)." This term was coined nearly half a century ago [18]. It is a fairly nonspecific term, and as noted above, the presence of "SIADH" can simply reflect subtle changes in posterior pituitary function accompanying trauma, tumor, or infection. More often, however, excessive ADH levels reflect an adverse reaction to a drug. 


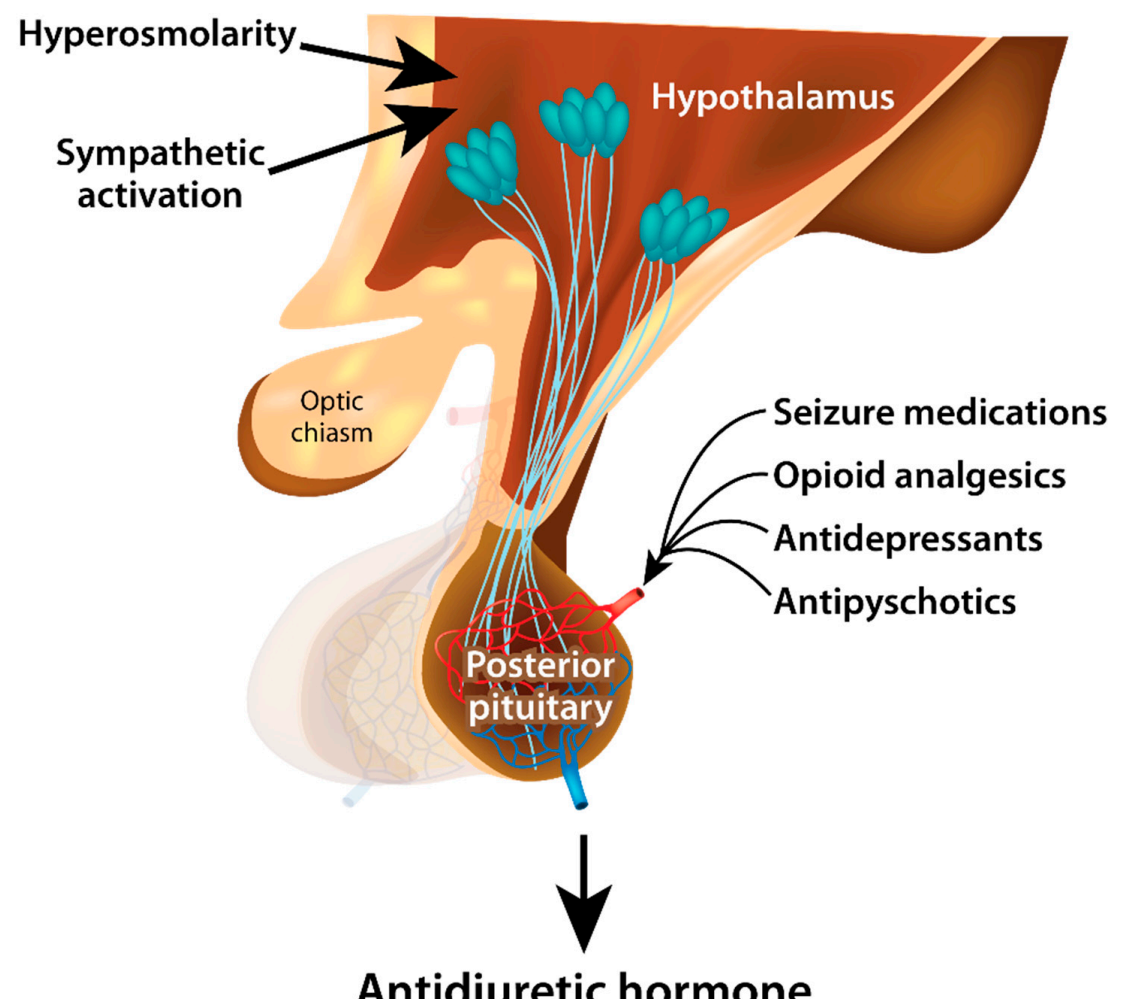

(A)

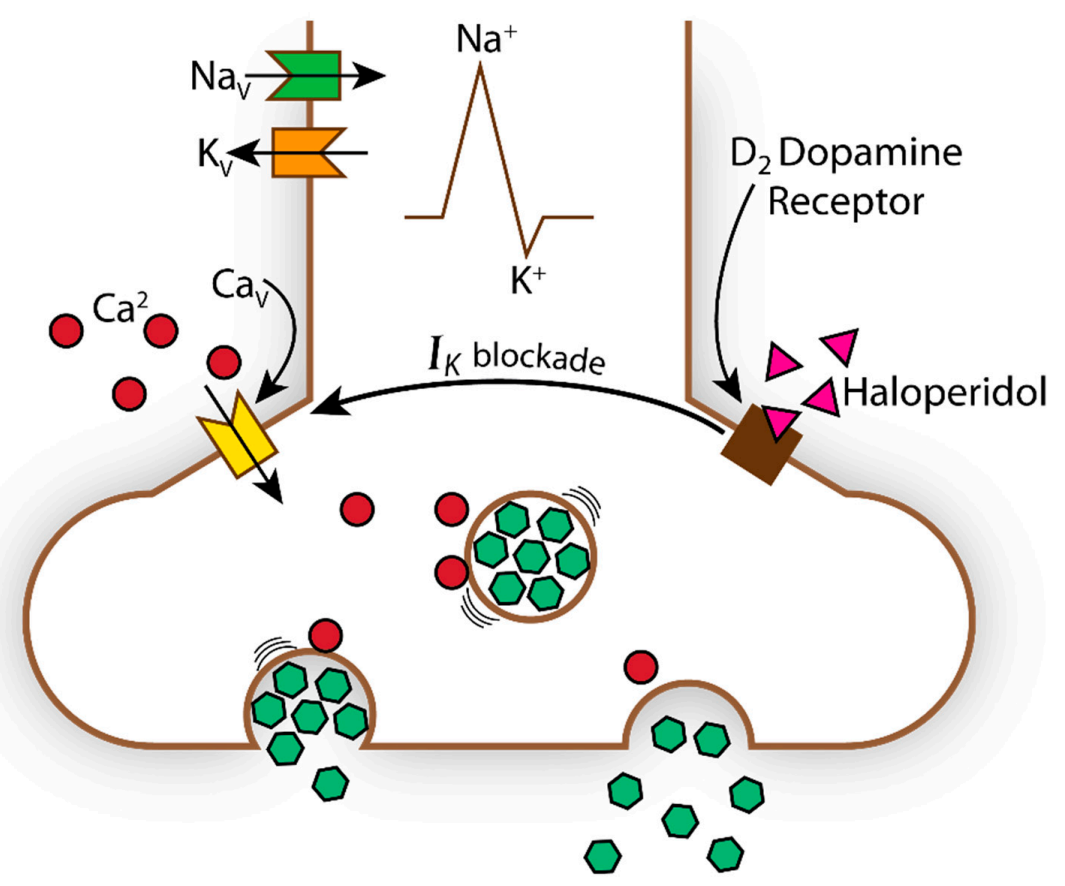

Antidiuretic hormone

(B)

Figure 1. (A) SIADH as an adverse drug reaction; (B) Peptidergic nerve terminals release ADH. 


\section{SIADH as an Adverse Drug Reaction}

Several classes of commonly used drugs are capable of causing SIADH through mechanisms involving the central nervous system. Many antidepressants (e.g., selective serotonin reuptake inhibitors, SSRIs) lead to increased release of ADH from the posterior pituitary by potentiating the activation of adrenergic receptors within the hypothalamus (Figure 1A). Data from the FDA Adverse Event Reporting System (AERS) have recently been leveraged to quantify the relationship between hyponatremia and antidepressant use based upon binding affinities for individual drugs to adrenergic receptor subtypes and serotonergic receptor subtypes, as well as to serotonin transporters, dopamine transporters, and norepinephrine transporters [19]. Using a linear regression model, the final adjusted reporting odds ratio for association between hyponatremia and antidepressant use was 1.91 (95\% confidence interval 1.83-2.00) [19]. A significant linear correlation was found for hyponatremia and binding affinity for the adrenergic receptors. The association was strongest for mirtazapine, followed by the SSRIs.

It has long been known that SSRIs can cause drug-induced SIADH. Hyponatremia occurs in as many as one in three patients taking an SSRI [20]. Many antipsychotic agents (including both typical and atypical dopamine receptor antagonists) also cause druginduced SIADH [21], in part by attenuating $\mathrm{K}^{+}$conductance within posterior pituitary nerve terminals [22]. An example is provided schematically in Figure 1B, wherein dopaminergic antagonists inadvertently alter ion channel function leading to excessive ADH release as an adverse drug reaction. Similar perturbations in posterior pituitary membrane conductance have been observed for opioid analgesics [23-25]. In clinical practice, however, the strength of association between opioids and SIADH does not appear to approach the magnitude of the association between SSRIs and SIADH [26]. Another class of drugs strongly associated with SIADH has been the anti-seizure drugs [27]. Carbamazepine and oxcarbazepine cause hyponatremia quite often [28]. As many as one in four patients using carbamazepine in a seizure clinic develop hyponatremia [29]. Like many of the drugs discussed above, these agents also increase circulating ADH levels through a central mechanism involving the regulation of membrane bound ion channels [30].

\section{Importance of Establishing Mechanism}

Mechanism is a key consideration when considering a diagnosis of drug-induced SIADH. Central causes of hyponatremia must be distinguished from peripheral causes. For example, nonsteroidal anti-inflammatory drugs (NSAIDs) such as naproxen can cause hyponatremia peripherally by potentiating the effects of $\mathrm{ADH}$ at the level of the kidney (altering prostaglandin levels in the loop of Henle and renal collecting ducts) [31]. This is not SIADH. Other agents, such as antineoplastic agents, are capable of causing hyponatremia through mechanisms that are both central and peripheral [32,33]. In order to accurately diagnose drug-induced SIADH, three conditions must be met. (1) There needs to be clear documentation of hypotonic hyponatremia caused by a disruption in pituitary homeostasis (i.e., retention of excess free water in the general circulation). (2) Paraneoplastic processes need to be ruled out, because some neuroendocrine tumors are capable of producing ADH ectopically [34]. (3) There needs to be a strong temporal relationship linking the hyponatremia with administration of a drug capable of altering posterior pituitary function [35].

"Naranjo's algorithm" is frequently used to assess causality for a variety of adverse drug reactions, based on temporal relationships (onset and resolution) in longitudinal datasets [20]. When already available, data regarding re-challenge are particularly helpful. However, given the high potential for morbidity and mortality accompanying druginduced hyponatremia, intentional re-challenge with a suspect drug should typically be avoided [36]. In general, the application of Naranjo's algorithm has been very effective at confirming drug-induced SIADH. In a cohort of 198 patients who had SIADH and a prior documented exposure to at least one suspect drug, nearly $75 \%$ of these cases 
were confirmed as drug-induced using Naranjo's algorithm [35]. This approach has been particularly effective at identifying cases of SIADH caused by SSRIs [20,35].

Once a diagnosis is confirmed, treatment of drug-induced SIADH varies according to the severity of the hyponatremia [37]. Many patients can simply be managed by removal of the offending agent and restriction of oral water intake. In some patients, clinicians also choose to attenuate the central secretion of ADH with demeclocycline [38] or optimize renal mobilization of free water with emerging agents such as SGLT-2 inhibitors [39]. Urea, loop diuretics, and selective $\mathrm{ADH} /$ vasopressin-receptor antagonists can also be used to increase free water excretion $[1,17]$. Conivaptan is an $\mathrm{ADH} /$ vasopressin antagonist available in an intravenous formulation for the treatment of severe SIADH. Tolvaptan is an oral formulation approved for use in patients with SIADH or hyponatremia due to congestive heart failure [40].

\section{The Need for Risk Stratification}

In summary, drug-induced SIADH is a common adverse drug reaction with potentially life-threatening consequences. It would therefore be advantageous to identify which patients are at highest risk prior to exposing them to drugs capable of altering neurohypophysial physiology. Although the field of pharmacogenetics has made great strides in assessing markers of risk for many clinically severe adverse drug reactions, the genetic architecture underlying drug-induced SIADH remains relatively uncharacterized. Large observational cohorts are now positioning themselves to address these and other similar questions retrospectively [41], and multi-institutional consortia are creating robust infrastructure to quantify the impact of gene-based dosing prospectively through pragmatic clinical trials involving many of these drugs [42].

In general, serum sodium level is a heritable trait. For baseline serum sodium levels, heritability estimates in twin studies have ranged from 0.41 ( $95 \%$ confidence interval: $0.35-0.46$ ) to 0.49 (95\% confidence interval: $0.43-0.54$ ) [43]. This means that nearly half of all variance in serum sodium levels may be attributable to genetic factors. Furthermore, early genome-wide association studies (GWAS) have also identified a small number of loci associated with serum sodium level in cohorts of unrelated individuals. NFAT5, for example, encodes a transcription factor that modulates intracellular response to hypertonic stress, and variants at this locus are associated with serum sodium level in individuals of varying ancestry [44]. Less is known, however, about genetic loci linked to change in serum sodium level over time (i.e., in longitudinal data rather than cross-sectional data). Some work has been conducted to identify loci impacting peripheral (renal) changes in salt and water homeostasis associated with diuretic use [45], but very little is known about the genetic determinants of centrally mediated changes in salt and water homeostasis including the changes seen in drug-induced SIADH.

Genes shown to influence drug response are typically categorized as either pharmacodynamic genes (influencing a drug's mechanism of action) or pharmacokinetic genes (influencing a drug's absorption, distribution, metabolism, or elimination) [46]. For druginduced SIADH, genes influencing mechanism of action would include receptors, Gproteins, and ion-channels expressed in the hypothalamus and the posterior pituitary (Figure 1A,B). While there is great variability in the genes known to encode many relevant receptors, transporters, and ion channels [47], very little work has been performed to quantify the impact of these variants on $\mathrm{ADH}$ release. There is evidence, however, to indicate that genetic variability within G-proteins can lead to SIADH. Variants in the stimulatory alpha subunit $(G s \alpha)$ known to regulate intracellular cyclic AMP levels have been reported in a patient with a neonatal form of SIADH [48].

Pharmacokinetic genes are also likely to increase the risk for drug-induced SIADH. Clearly, variability in pharmacokinetic genes can lead to serious adverse outcomes for many of the drugs discussed in this review. Cytochrome P450 (CYP) 2C19, for example, metabolizes $5-10 \%$ of all prescription drugs, and loss of function alleles at the CYP2C19 gene locus are known to increase risk for potentially lethal ventricular arrhythmias in patients 
using three commonly prescribed SSRIs: sertraline, citalopram, and escitalopram $[49,50]$. Furthermore, loss of function alleles at the CYP2D6 locus increase patient risk for ventricular arrhythmias in the context of three other SSRIs: fluoxetine, fluvoxamine, and paroxetine [49,51]. Similar associations exist for CYP2D6 variants and therapeutic failure in the context of opioids [52,53], and variants in a third candidate cytochrome P450 gene, CYP2C9, have also been linked to altered outcomes for anti-seizure drugs [54,55].

Pharmacogenetic tests are already being deployed clinically to guide prescribing for many drugs discussed in this review. However, the implementation of these tests is currently based on known association with severe adverse drug reactions other than SIADH. For example, decision support already exists within electronic medical records at some academic institutions to optimize the efficacy of SSRIs and reduce the frequency of adverse events such as electrocardiographic abnormalities associated with their use $[50,56]$. It is highly likely that the same gene-based dosing approach would reduce the frequency of SIADH associated with the use of SSRIs. Because drug-induced SIADH is associated with significant morbidity (cognitive changes, gait instability and falls) and mortality (cerebral edema, seizures, and death), the genetic architecture underlying this common adverse drug reaction needs to be defined in multi-institutional cohorts.

Funding: This work was funded in part by the National Institutes of Health (U01HG007253), as well as through a generous gift from T. Denny Sanford that created Imagenetics (merging internal medicine and genetics).

Institutional Review Board Statement: Not applicable.

Informed Consent Statement: Not applicable.

Acknowledgments: R. A. Wilke wishes to thank Eric Dalseide in medical graphics at the University of South Dakota Sanford School of Medicine for assistance with construction of Figure 1.

Conflicts of Interest: R. A. Wilke declares no conflict of interest.

\section{References}

1. Hoorn, E.J.; Zietse, R. Diagnosis and treatment of hyponatremia: Compilation of the guidelines. J. Am. Soc. Nephrol. 2017, 28, 1340-1349. [CrossRef] [PubMed]

2. Peri, A. Management of hyponatremia: Causes, clinical aspects, differential diagnosis and treatment. Expert Rev. Endocrinol. Metab. 2019, 14, 13-21. [CrossRef]

3. Burst, V. Etiology and epidemiology of hyponatremia. Front. Horm. Res. 2019, 52, 24-35. [CrossRef] [PubMed]

4. Berni, A.; Malandrino, D.; Corona, G.; Maggi, M.; Parenti, G.; Fibbi, B.; Poggesi, L.; Bartoloni, A.; Lavorini, F.; Fanelli, A.; et al. Serum sodium alterations in SARS CoV-2 (COVID-19) infection: Impact on patient outcome. Eur. J. Endocrinol. 2021, 185, 137-144. [CrossRef] [PubMed]

5. Sterns, R.H.; Silver, S.M. Complications and management of hyponatremia. Curr. Opin. Nephrol. Hypertens. 2016, 25, 114-119. [CrossRef] [PubMed]

6. Carpenter, C.R.; Hammouda, N.; Linton, E.A.; Doering, M.; Ohuabunwa, U.K.; Ko, K.J.; Hung, W.W.; Shah, M.N.; Lindquist, L.A.; Biese, K.; et al. Delirium Prevention, Detection, and Treatment in Emergency Medicine Settings: A Geriatric Emergency Care Applied Research (GEAR) Network Scoping Review and Consensus Statement. Acad. Emerg. Med. 2021, 28, 19-35. [CrossRef]

7. Hoel, R.W.; Giddings Connolly, R.M.; Takahashi, P.Y. Polypharmacy management in older patients. Mayo Clin. Proc. 2021, 96, 242-256. [CrossRef] [PubMed]

8. Mannesse, C.K.; Vondeling, A.M.; van Marum, R.J.; van Solinge, W.W.; Egberts, T.C.; Jansen, P.A. Prevalence of hyponatremia on geriatric wards compared to other settings over four decades: A systematic review. Ageing Res. Rev. 2013, 12, 165-173. [CrossRef] [PubMed]

9. Boyer S, Gayot C, Bimou C, Mergans T, Kajeu P, Castelli M, Dantoine T, Tchalla A. Prevalence of mild hyponatremia and its association with falls in older adults admitted to an emergency geriatric medicine unit (the MUPA unit). BMC Geriatr. 2019, 19, 265. [CrossRef]

10. Ramírez, E.; Rodríguez, A.; Queiruga, J.; García, I.; Díaz, L.; Martínez, L.; Muñoz, R.; Muñoz, M.; Tong, H.Y.; Martínez, J.C.; et al. Severe Hyponatremia Is Often Drug Induced: 10-Year Results of a Prospective Pharmacovigilance Program. Clin. Pharmacol. Ther. 2019, 106, 1362-1379. [CrossRef] [PubMed]

11. Oh, R.C.; Malave, B.; Chaltry, J.D. Collapse in the heat-From overhydration to the emergency room-Three cases of exerciseassociated hyponatremia associated with exertional heat illness. Mil. Med. 2018, 183, e225-e228. [CrossRef] [PubMed] 
12. Rodriguez, M.; Hernandez, M.; Cheungpasitporn, W.; Kashani, K.B.; Riaz, I.; Rangaswami, J.; Herzog, E.; Guglin, M.; Krittanawong, C. Hyponatremia in Heart Failure: Pathogenesis and Management. Curr. Cardiol. Rev. 2019, 15, 252-261. [CrossRef] [PubMed]

13. Rotondo, F.; Butz, H.; Syro, L.V.; Yousef, G.M.; Di Ieva, A.; Restrepo, L.M.; Quintanar-Stephano, A.; Berczi, I.; Kovacs, K. Arginine vasopressin (AVP): A review of its historical perspectives, current research and multifunctional role in the hypothalamohypophysial system. Pituitary 2016, 19, 345-355. [CrossRef] [PubMed]

14. Sparapani, S.; Millet-Boureima, C.; Oliver, J.; Mu, K.; Hadavi, P.; Kalostian, T.; Ali, N.; Avelar, C.M.; Bardies, M.; Barrow, B.; et al. The Biology of Vasopressin. Biomedicines 2021, 9, 89. [CrossRef]

15. Tudor, R.M.; Thompson, C.J. Posterior pituitary dysfunction following traumatic brain injury: Review. Pituitary 2019, 22, 296-304. [CrossRef] [PubMed]

16. Brault, C.; Flahaut, G.; Maizel, J.; Choukroun, G. Hyponatremia in a Patient with Central Nervous System Lymphoma. Am. J. Kidney Dis. 2016, 68, A17-A19. [CrossRef] [PubMed]

17. Misra, U.K.; Kalita, J.; Tuberculous Meningitis International Research Consortium. Mechanism, spectrum, consequences and management of hyponatremia in tuberculous meningitis. Wellcome Open Res. 2021, 4, 189. [CrossRef]

18. Schwartz, W.B.; Bennett, W.; Curelop, S.; Bartter, F.C. A syndrome of renal sodium loss and hyponatremia probably resulting from inappropriate secretion of antidiuretic hormone. Am. J. Med. 1957, 23, 529-542. [CrossRef]

19. Mazhar, F.; Pozzi, M.; Gentili, M.; Scatigna, M.; Clementi, E.; Radice, S.; Carnovale, C. Association of Hyponatraemia and Antidepressant Drugs: A Pharmacovigilance-Pharmacodynamic Assessment Through an Analysis of the US Food and Drug Administration Adverse Event Reporting System (FAERS) Database. CNS Drugs 2019, 33, 581-592. [CrossRef] [PubMed]

20. Jacob, S.; Spinler, S.A. Hyponatremia associated with selective serotonin-reuptake inhibitors in older adults. Ann. Pharmacother. 2006, 40, 1618-1622. [CrossRef] [PubMed]

21. Mazhar, F.; Battini, V.; Pozzi, M.; Invernizzi, E.; Mosini, G.; Gringeri, M.; Capuano, A.; Scavone, C.; Radice, S.; Clementi, E.; et al. Hyponatremia Following Antipsychotic Treatment: In Silico Pharmacodynamics Analysis of Spontaneous Reports from the US Food and Drug Administration Adverse Event Reporting System Database and an Updated Systematic Review. Int. J. Neuropsychopharmacol. 2021, 24, 477-489. [CrossRef] [PubMed]

22. Wilke, R.A.; Hsu, S.F.; Jackson, M.B. Dopamine D4 receptor mediated inhibition of potassium current in neurohypophysial nerve terminals. J. Pharmacol. Exp. Ther. 1998, 284, 542-548.

23. Lupardus, P.J.; Wilke, R.A.; Aydar, E.; Palmer, C.P.; Chen, Y.; Ruoho, A.E.; Jackson, M.B. Membrane-delimited coupling between sigma receptors and $\mathrm{K}^{+}$channels in rat neurohypophysial terminals requires neither G-protein nor ATP. J Physiol. 2000, 526, 527-539. [CrossRef] [PubMed]

24. Scott, V.; Bishop, V.R.; Leng, G.; Brown, C.H. Dehydration-induced modulation of kappa-opioid inhibition of vasopressin neurone activity. J Physiol. 2009, 587, 5679-5689. [CrossRef] [PubMed]

25. Na, E.S.; Morris, M.J.; Johnson, A.K. Opioid mechanisms that mediate the palatability of and appetite for salt in sodium replete and deficient states. Physiol. Behav. 2012, 106, 164-170. [CrossRef] [PubMed]

26. Falhammar, H.; Calissendorff, J.; Skov, J.; Nathanson, D.; Lindh, J.D.; Mannheimer, B. Tramadol- and codeine-induced severe hyponatremia: A Swedish population-based case-control study. Eur. J. Int. Med. 2019, 69, 20-24. [CrossRef] [PubMed]

27. Seifert, J.; Letmaier, M.; Greiner, T.; Schneider, M.; Deest, M.; Eberlein, C.K.; Bleich, S.; Grohmann, R.; Sermin Toto, S. Psychotropic drug-induced hyponatremia: Results from a drug surveillance program-An update. J. Neural Transm. 2021, 128, 1249-1264. [CrossRef] [PubMed]

28. Lu, X.; Wang, X. Hyponatremia induced by antiepileptic drugs in patients with epilepsy. Expert Opin. Drug Saf. 2017, 16, 77-87. [CrossRef]

29. Berghuis, B.; van der Palen, J.; de Haan, G.J.; Lindhout, D.; Koeleman, B.P.C.; Sander, J.W.; EpiPGX Consortium. Carbamazepineand oxcarbazepine-induced hyponatremia in people with epilepsy. Epilepsia 2017, 58, 1227-1233. [CrossRef]

30. Fricke-Galindo, I.; LLerena, A.; Jung-Cook, H.; López-López, M. Carbamazepine adverse drug reactions. Expert Rev. Clin. Pharmacol. 2018, 11, 705-718. [CrossRef]

31. Chiu, C.Y.; Sarwal, A.; Azhar Munir, R.; Widjaja, M.; Khalid, A.; Khanna, R. Syndrome of inappropriate antidiuretic hormone (SIADH) induced by long-term use of citalopram and short-term use of naproxen. Am. J. Case Rep. 2020, 21, e926561. [CrossRef] [PubMed]

32. Verzicco, I.; Regolisti, G.; Quaini, F.; Bocchi, P.; Brusasco, I.; Ferrari, M.; Passeri, G.; Cannone, V.; Coghi, P.; Fiaccadori, E.; et al. Electrolyte Disorders Induced by Antineoplastic Drugs. Front. Oncol. 2020, 10, 779. [CrossRef]

33. Krishnamurthy, A.; Bhattacharya, S.; Lathia, T.; Kantroo, V.; Kalra, S.; Dutta, D. Anticancer medications and sodium dysmetabolism. Eur. Endocrinol. 2020, 16, 122-130. [CrossRef] [PubMed]

34. Zhao, C.F.; Zhao, S.F.; Du, Z.Q. Small cell carcinoma of the cervix complicated by syndrome of inappropriate antidiuretic hormone secretion: A case report. J. Int. Med. Res. 2021, 49, 300060520985657. [CrossRef]

35. Shepshelovich, D.; Schechter, A.; Calvarysky, B.; Diker-Cohen, T.; Rozen-Zvi, B.; Gafter-Gvili, A. Medication-induced SIADH: Distribution and characterization according to medication class. Br. J. Clin. Pharmacol. 2017, 83, 1801-1807. [CrossRef] [PubMed]

36. Liamis, G.; Megapanou, E.; Elisaf, M.; Milionis, H. Hyponatremia-Inducing Drugs. Front. Horm. Res. 2019, 52, 167-177. [CrossRef] 
37. Faiver, L.; Hensler, D.; Rush, S.C.; Kashlan, O.; Williamson, C.A.; Rajajee, V. Safety and Efficacy of $23.4 \%$ Sodium Chloride Administered via Peripheral Venous Access for the Treatment of Cerebral Herniation and Intracranial Pressure Elevation. Neurocrit. Care 2021. [CrossRef] [PubMed]

38. Miell, J.; Dhanjal, P.; Jamookeeah, C. Evidence for the use of demeclocycline in the treatment of hyponatraemia secondary to SIADH: A systematic review. Int. J. Clin. Pract. 2015, 69, 1396-1417. [CrossRef] [PubMed]

39. Sarafidis, P.; Loutradis, C.; Ferro, C.J.; Ortiz, A. SGLT-2 Inhibitors to Treat Hyponatremia Associated with SIADH: A Novel Indication? Am. J. Nephrol. 2020, 51, 553-555. [CrossRef] [PubMed]

40. Verbalis, J.G.; Goldsmith, S.R.; Greenberg, A.; Korzelius, C.; Schrier, R.W.; Sterns, R.H.; Thompson, C.J. Diagnosis, evaluation, and treatment of hyponatremia: Expert panel recommendations. Am. J. Med. 2013, 126, S1-S42. [CrossRef] [PubMed]

41. Denny, J.C.; Rutter, J.L.; Goldstein, D.B.; Philippakis, A.; Smoller, J.W.; Jenkins, G.; Dishman, E.; All of Us Research Program Investigators. The "All of Us" Research Program. N. Engl. J. Med. 2019, 381, 668-676. [CrossRef] [PubMed]

42. Duong, B.Q.; Arwood, M.J.; Hicks, J.K.; Beitelshees, A.L.; Franchi, F.; Houder, J.T.; Limdi, N.A.; Cook, K.J.; Owusu Obeng, A.; Petry, N.; et al. Development of Customizable Implementation Guides to Support Clinical Adoption of Pharmacogenomics: Experiences of the Implementing GeNomics In pracTicE (IGNITE) Network. Pharm. Pers. Med. 2020, 13, 217-226. [CrossRef] [PubMed]

43. Timmons, A.K.; Korpak, A.M.; Tan, J.; Moore, K.P.; Liu, C.H.; Forsberg, C.W.; Goldberg, J.; Smith, N.L.; Cohen, D.M. Heritability and individuality of the plasma sodium concentration: A twin study in the United States veteran population. Am. J. Physiol. Renal. Physiol. 2019, 316, F1114-F1123. [CrossRef] [PubMed]

44. Böger, C.A.; Gorski, M.; McMahon, G.M.; Xu, H.; Chang, Y.C.; van der Most, P.J.; Navis, G.; Nolte, I.M.; de Borst, M.H.; Zhang, W.; et al. NFAT5 and SLC4A10 loci associate with plasma osmolality. J. Am. Soc. Nephrol. 2017, 28, 2311-2321. [CrossRef] [PubMed]

45. Ware, J.S.; Wain, L.V.; Channavajjhala, S.K.; Jackson, V.E.; Edwards, E.; Lu, R.; Siew, K.; Jia, W.; Shrine, N.; Kinnear, S.; et al Phenotypic and pharmacogenetic evaluation of patients with thiazide-induced hyponatremia. J. Clin. Investig. 2017, 127, 3367-3374. [CrossRef] [PubMed]

46. Wilke, R.A.; Reif, D.M.; Moore, J.H. Combinatorial pharmacogenetics. Nat. Rev. Drug Discov. 2005, 4, 911-918. [CrossRef] [PubMed]

47. Alexander, S.P.H.; Christopoulos, A.; Davenport, A.P.; Kelly, E.; Mathie, A.; Peters, J.A.; Veale, E.L.; Armstrong, J.F.; Faccenda, E.; Harding, S.D.; et al. The concise guide to pharmacology 2019/20: G protein-coupled receptors. Br. J. Pharmacol. 2019, 176 (Suppl. 1), S21-S141. [CrossRef] [PubMed]

48. Wentworth, K.; Hsing, A.; Urrutia, A.; Zhu, Y.; Horvai, A.E.; Bastepe, M.; Hsiao, E.C. A Novel T55A Variant of Gs alpha Associated with Impaired cAMP Production, Bone Fragility, and Osteolysis. Case Rep. Endocrinol. 2016, 2016, 2691385. [CrossRef] [PubMed]

49. Hicks, J.K.; Bishop, J.R.; Sangkuhl, K.; Müller, D.J.; Ji, Y.; Leckband, S.G.; Leeder, J.S.; Graham, R.L.; Chiulli, D.L.; LLerena, A.; et al. Clinical Pharmacogenetics Implementation Consortium guideline for CYP2D6 and CYP2C19 genotypes and dosing of selective serotonin reuptake inhibitors. Clin. Pharmacol. Ther. 2015, 98, 127-134. [CrossRef] [PubMed]

50. Petry, N.; Lupu, R.A.; Gohar, A.; Larson, E.A.; Peterson, C.; Williams, V.; Zhao, J.; Wilke, R.A.; Hines, L. CYP2C19 genotype, physician prescribing pattern, and risk for long QT on SSRIs. Pharmacogenomics 2019, 20, 343-351. [CrossRef] [PubMed]

51. Hicks, J.K.; Bishop, J.R.; Gammal, R.S.; Sangkuhl, K.; Bousman, C.A.; Leeder, J.S.; Llerena, A.; Mueller, D.J.; Ramsey, L.B.; Scott, S.A.; et al. A Call for Clear and Consistent Communications Regarding the Role of Pharmacogenetics in Antidepressant Pharmacotherapy. Clin. Pharmacol. Ther. 2020, 107, 50-52. [CrossRef]

52. Crews, K.R.; Gaedigk, A.; Dunnenberger, H.M.; Leeder, J.S.; Klein, T.E.; Caudle, K.E.; Haidar, C.E.; Shen, D.D.; Callaghan, J.T.; Sadhasivam, S.; et al. Clinical Pharmacogenetics Implementation Consortium guidelines for cytochrome P450 2D6 genotype and codeine therapy: 2014 update. Clin. Pharmacol. Ther. 2014, 95, 376-382. [CrossRef] [PubMed]

53. Crews, K.R.; Monte, A.A.; Huddart, R.; Caudle, K.E.; Kharasch, E.D.; Gaedigk, A.; Dunnenberger, H.M.; Leeder, J.S.; Callaghan, J.T.; Samer, C.F.; et al. Clinical Pharmacogenetics Implementation Consortium Guideline for CYP2D6, OPRM1, and COMT Genotypes and Select Opioid Therapy. Clin. Pharmacol. Ther. 2021. [CrossRef] [PubMed]

54. Caudle, K.E.; Rettie, A.E.; Whirl-Carrillo, M.; Smith, L.H.; Mintzer, S.; Lee, M.T.; Klein, T.E.; Callaghan, J.T.; Clinical Pharmacogenetics Implementation Consortium. Clinical pharmacogenetics implementation consortium guidelines for CYP2C9 and HLA-B genotypes and phenytoin dosing. Clin. Pharmacol. Ther. 2014, 96, 542-548. [CrossRef]

55. Karnes, J.H.; Rettie, A.E.; Somogyi, A.A.; Huddart, R.; Fohner, A.E.; Formea, C.M.; Ta Michael Lee, M.; Llerena, A.; Whirl-Carrillo, M.; Klein, T.E.; et al. Clinical Pharmacogenetics Implementation Consortium (CPIC) Guideline for CYP2C9 and HLA-B Genotypes and Phenytoin Dosing: 2020 Update. Clin. Pharmacol. Ther. 2021, 109, 302-309. [CrossRef] [PubMed]

56. Cavallari, L.H.; Weitzel, K.W.; Elsey, A.R.; Liu, X.; Mosley, S.A.; Smith, D.M.; Staley, B.J.; Winterstein, A.G.; Mathews, C.A.; Franchi, F.; et al. University of Florida Health Personalized Medicine Program. Pharmacogenomics 2017, 18, 421-426. [CrossRef] [PubMed] 